\begin{tabular}{|c|c|c|}
\hline 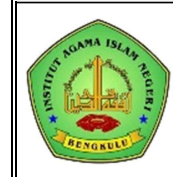 & $\begin{array}{l}\text { A1 Fitrah } \\
\text { Journal Of Early Childhood Islamic Education } \\
\text { ISSN : 2599-2287 E-ISSN : 2622-335X } \\
\text { Vol.2 No.1 Juli } 2018\end{array}$ & $\begin{array}{r}\text { Level Pemahaman Matematika Model } \\
\text { Pirie dan Kieren Pada Anak Usia Dini } \\
\text { Dodi Isran }\end{array}$ \\
\hline
\end{tabular}

\title{
LEVEL PEMAHAMAN MATEMATIKA MODEL PIRIE DAN KIEREN PADA ANAK USIA DINI
}

\begin{abstract}
Abstrak
Dodi Isran

Matematika adalah salah satu ilmu yang penting dalam kehidupan manusia. Matematika merupakan pelajaran yang mendasarkan pada pola pemikiran siswa pada angka, simbol dan geometri yang dapat digunakan dalam kehidupan sehari-hari. Level pemahaman matematika sangat mendasari dari perkembangan pemahaman matematika siswa anak sia dini. Maka perlu dikembangkan pemahaman matematikasejak dini. Teori pembelajaran matematika yang cukup dikenal dan sering digunakan dalam hal penelitian dalam bidang pembelajaran matematika diantaranya adalah Teori APOS dari Ed Dubinsky, teori Van Hilele, teori pemahaman matematika (Model Pirie Dan Kirere), teori Bruner, teori Piaget dan masih banyak lagi teori-teori belajar yang dapat digunakan dalam pembelajaran matematika. Dalam tulisan ini akan lebih dijelaskan tentang level pemahaman matematika siswa usia dini berdasarkan model Pirie dan Keiren. Level perkembangan pemahaman matematika model Pirie dan Kirien antara lain adalah primitive knowing $(\mathrm{Pk})$, image making (Im), image having (Ih), property noticing ( $\mathrm{Pn})$, formalising (F), observising (O), structuring (S), dan inventising (Iv).

Kata Kunci : Level Pemahaman Matematika, Model Pirie dan Kieren

dodi@stiesnu-bengkulu.ac.id

Sekolah Tinggi Ilmu Ekonomi

Syariah Nahdlatul Ulama

Bengkulu
\end{abstract}

\section{Pendahuluan}

Matematika adalah salah satu ilmu yang penting dalam kehidupan manusia. Hal ini juga yang mendasari matematika menjadi pelajaran yang dikenalkan kepada siswa sejak usia dini sampai perguruan tinggi. Matematika merupakan pelajaran yang mendasarkan pada pola pemikiran siswa pada angka, simbol dan geometri yang dapat digunakan dalam kehidupan sehari-hari. Meskipun banyak yang telah memahami matematika adalah ilmu yang penting, kenyataannya matematika masih dipandang sebagai mata pelajaran yang menakutkan.

Untuk menghindari hal tersebut, matematika hendaknya penting diperkenalkan sejak dini Sehingga perkembangan Pemahaman matematika 


\begin{tabular}{|l|l||r|}
\hline & Al Fitrah & \\
Journal Of Early Childhood Islamic Education & Level Pemahaman Matematika Model \\
ISSN : 2599-2287 E-ISSN : 2622-335X & Pirie dan Kieren Pada Anak Usia Dini \\
& Dodi Isran \\
\hline
\end{tabular}

dapat berkembang dari pemahaman awal yang baik. Perkembangan pemahaman matematika telah banyak dipelajari berdasarkan beberapa teori pembelajaran matematika. Teori pembelajaran matematika yang cukup terkenal dan sering digunakan dalam hal penelitian dalam bidang pembelajaran matematika diantaranya adalah Teori APOS dari Ed Dubinsky, teori Van Hiele, teori pemahaman matematika (Model Pirie Dan Kieren)a teori Bruner, teori Piaget dan masih banyak lagi teori-teori belajar yang dapat digunakan dalam pembelajaran matematika.

Hal yang mendasari dalam pembelajaran matematika adalah bagaimana pemahaman matematika itu sendiri, seperti yang di ungkapkan pada teori Model Pirie Dan Kieren. Pirie dan Kieren yang dikembangkan sejak tahun 1994. Model ini menyatakan bahwa dalam memandang pemahaman Sebagai sebuah proses perkembangan yang utuh, dinamis, berlapis tetapi tidak linear,dan pernah berakhir. Pada model ini menolak konsep pemahaman sebagai sebuah fungsi yang naik secara monoton. Model ini membagi level pemahaman matematika siswa kedalam delapan tingkatan pemahaman. ${ }^{1}$ Maka dalam tulisan ini akan membahas lebih detail tentang level pemahaman matematika Model Pirie Dan Kieren pada anak usia dini .

\section{Pengajaran Matematika Pada Anak}

\section{Usia Dini}

Pengajaran matematika di PAUD memuat dua bidang inti, yaitu (1) bilangan dan (2) geometri dan pengukuran. Kedua bidang tersebut penting sebagai persiapan sekolah dan penting dalam kehidupan sehari-hari ${ }^{2}$.

Berdasarkan National Council. Of Teacher Of Mathematics (NCTM) telah mengembangkan The principles and strandards for school mathematics (prinsip dan standar untuk matematika sekolah) memaparkan harapan matematika pada anak usia dini tentang konsep-konsep yang bisa dipahami anak usia dalam matematika antara lain ${ }^{3}$ :

1. Bilangan

Ada konsep matematika yang paling penting dipelajari anak adalah pengembangan kepekaan bilangan. Peka terhadap bilangan berarti tidak

\footnotetext{
${ }^{1}$ Pirie, S., Kieren, T. (1989). A recursive theory of mathematical understanding. For the Learning of Mathematics, 9(3), hal. 11.

2 Novikasari, ifada (2016) Matematika dalam Program Pendidikan Anak Usia Dini (PAUD). Bunayya: Jumal Pendidikan Anak, Vol 2 (1). Hal. 8.

3 NCTM. Principles and Standars for School Mathematics. Reston, VA: NCTM. 2000. Hlm. 67
} 


\begin{tabular}{|l|l||r|}
\hline A1 Fitrah & Level Pemahaman Matematika Model \\
\hline Journal Of Early Childhood Islamic Education & Pirie dan Kieren Pada Anak Usia Dini \\
ISSN : 2599-2287 E-ISSN : 2622-335X & Dodi Isran \\
Vol.2 No.1 Juli 2018 & \\
\hline
\end{tabular}

sekedar menghitung. Bagaimana kepekaan bilangan itu mencakup pengembangan rasa kuantitas dan pemahaman kesesuaian satu lawan satu. Ketika kepekaan terhadap bilangan anak-anak berkembang, mereka menjadi semakin tertarik pada hitungmenghitung, Untuk itu, menghitung ini menjadi landaSan bagi pekerjaan dini anak-anak dengan bilangan.

2. Aljabar

Sebuah pengenalan aljabar dimulai dengan menyortir, menggolongkan, membandingkan, dan menyusun benda-benda menurut bentuk, jumlah, dan sifat-sifat lain, mengenal, menggambarkan, serta memperluas pola akan memberi sumbangan kepada pemahaman anak-anak tentang Penggolongan.

3. Penggolongan

Pengklasifikasian ini adalah salah satu proses yang penting untuk mengembangakn konsep bilangan. Supaya anak mampu menggolongkan atau menyortir benda-banda, mereka harus mengem bangkan pengertian tentang "saling memiliki kesamaan", 66 keserupaan”, “kesamaan”, dan "perbedaan".

4. Pola-pola
Sebuah pola mengidentifikasi dan menciptakan dihubungkan dengan penggolongan dan penyertiran. Anak usia dini mulai melihat atribut-atribut yag sama dan berbeda pada gambar dan bendabenda. Anak usia dini senang membuat pola di lingkungan mereka.

5. Geometri

Dalam membangun konsep geometri pada anak di mulai dengan mengidentifikasi bentuk-bentuk, menyelidiki bangunan dan memisahkan gambar-gambar biasa seperti segi empat, lingkaran dan segitiga. Anak usia dini belajar konsep letak seperti dibawah, di atas, kiri, kanan meletakkan dasar awal memahami geometri.

6. Pengukuran

Anak usia dini mempunyai kesempatan untuk pengalaman pengalaman langsung untuk mengukur, menimbang, dan membandingkan ukuran bendabenda, mereka belajar konsep pengukuran. Pengalaman ini ' anak akan mengembangkan sebuah dasar kuat dalam konsep-konsep pengukuran. 


\begin{tabular}{|l|l|r|}
\hline \begin{tabular}{|l|l|}
\hline \\
$y$
\end{tabular} & Al Fitrah \\
Journal Of Early Childhood Islamic Education & Level Pemahaman Matematika Model \\
ISSN : 2599-2287 E-ISSN : 2622-335X & Pirie dan Kieren Pada Anak Usia Dini \\
& Dodi Isran \\
\hline
\end{tabular}

7. Analisis data dan probabilitas

Beberapa percobaan dengan pengukuran, penggolongan, dan penyortiran merupakan dasar untuk memahami probabilitas dan analisis data. Yang berarti mengemukakan pertanyaan, mengumpulkan informasi tentang dirinya dan lingkungan mereka, dan menyampaikan informasi ini secara hidup.

\section{Hubungan Model Teori Pirie Klerin}

\section{Dan Teori Apos}

Berdasarkan $\mathrm{Meel}^{4}$. mengaitkan teori APOS dari Dubinsky dengan teori pemahaman Pirie dan Kieren. Dia membagi teori pemahaman Pirie dan Kieren ke dalam empat unit berbeda yang serupa dengan empat level dari teori APOS Dubinsky. Lapisan primitive knowing dan image making berkorespondensi dengan konsepsi aksi, lapisan image having dan property noticing berkorespondensi dengan konsepsi proses, lapisan formalising dan observing berkorespondensi dengan konsepsi objek, dan terakhir lapisan structuring dan inventising mengorganisir sebuah struktur yang serupa dengan konsepsi skema. Lebih

\footnotetext{
${ }^{4}$ Fatrima, op. cit. Hal. 49
}

jelas tentang kaitan teori APOS dan teori pem ahaman Pirie dan Kieren yang dikemukakan Meel disajikan dalam Tabel 1 berikut ini:

Tabel 1 Kaitan Teori APOS dan Teori Pemahaman Pirie Dan Kieren

\begin{tabular}{|r|r|}
\hline $\begin{array}{c}\text { Teori APOS dari } \\
\text { Dubinsky }\end{array}$ & $\begin{array}{r}\text { Teori Pemahaman } \\
\text { Pirie Dan Kieren }\end{array}$ \\
\hline \multirow{2}{*}{ Aksi } & Primitive knowing \\
\cline { 2 - 2 } Proses & Image making \\
\cline { 2 - 2 } & Property noticing \\
\hline \multirow{2}{*}{ Objek } & Formalisisng \\
\cline { 2 - 2 } & Observising \\
\hline \multirow{2}{*}{ Skema } & Structuring \\
\cline { 2 - 2 } & Inventising \\
\hline
\end{tabular}

Berdasarkan pandangan Meel tersebut dapat terlihat bahwa kaitan kedua teori tersebut sangat berhubungan dimana Teori APOS mendasari pelevelan menjadi 4 level yang membagi dari delapan level pemahaman matematika menurut Pirie dan Kieren mengembangkan kedelapan level tersebut menjadi beberapa pelevelan yang dapat diujikan pada sebuah penelitian pendidikan matematika anak usia dini. 


\begin{tabular}{|l|l|r|}
\hline & Al Fitrah & Level Pemahaman Matematika Model \\
Journal Of Early Childhood Islamic Education & Pirie dan Kieren Pada Anak Usia Dini \\
ISSN : 2599-2287 E-ISSN : 2622-335X & Dodi Isran \\
\hline & & \\
\hline
\end{tabular}

\section{Level Pemahaman Matematika Model}

\section{Pirie Dan Kieren}

Pemahaman matematika tersusun atas dua kata, yaitu Pemahaman dan matematika. Pemahaman dapat merujuk pada bagaimana siswa mampu mengerti benar yang dibuktikan serta mampu memberikan penjelasan. Seseorang dapat dikatakan paham terhadap suatu hal, jika seseorang tersebut mengerti benar dan mampu menjelaskan suatu hal yang diapahaminya. Sedangkan matematika adalah salah satu ilmu yang berkaitan dengan angka, simbol dan geometri. Sehingga pemahaman matematika dapat diartikan sebagai kemampuan bukukan seseorang dalam mem serta mampu memberikan masalah angka, simbol dan geometn.

Beberapa penelitian penelitian yang menggambarkan pemahaman matematika dalam hal struktur representasi pengetahuan individu salah satunya adalah Hiebert dan Carpenter ${ }^{5}$ mendefinisikan pemahaman sebagai "membuat koneksi antara ide, fakta, atau prosedur" yaitu pada tingkat pemahaman secara langsung berkaitan dengan karakteristik koneksi.

${ }^{5}$ Hiebert, J .,\& Carpenter, TP. Learning and teaching with understanding. In D.A. Grouws (Ed.), Handbook of research on mathematics teaching and learning. NY: MacMillian. (1992). Hal. 67
Sedangkan untuk level Pemahaman matematika di ungkapkan oleh Model Pirie Dan Kierin. Teori Pirie Dan Kieren telah banyak sekali digunakan oleh beberapa peneliti baik dalam pembelajaran matematika khususnya. Penelitian berkaitan dengan model pemahaman Pirie dan Kieren diantaranya dilakukan oleh: Kastberg (2002), Slaten (2006), Parameswara (2010), dan Droujkova dkk (2005). Kastberg (2002) menggunakan model pemahaman Pirie dan Kieren pada kasus fungsi logaritma. Slaten (2006) menggunakan model pemahaman Pirie dan Kieren untuk meneliti keefektivan pembelajaran geometri. Parameswara (2010) menggunakan model pemahaman Pirie dan Kieren untuk meneliti pendekatan matematikawan dalam pemahaman definisi. Droujkova (2005) meneliti tentang kerangka kerja konseptual untuk guru kaitannya dengan model Pirie dan Kieren, ditemukan adanya pemahaman kolektif. ${ }^{6}$

Level perkembangan pemahaman matematika model Pirie dan Kieren

\footnotetext{
6 Susiswo, Folding Back Mahasiswa Dalam Menyelesaikan Masalah Limit Berdasarkan Pengetahuan Konseptual Dan Pengetahuan Prosedural. Dalam Prosiding Seminar Nasional TEQIP (Teachers Quality Improvement Program) dengan tema "Membangun Karakter Bangsa melalui Pembelajaran Bermakna TEQIP" pada 1 Desember 2014 di Universitas Negeri Malang. ha]. 1
} 


\begin{tabular}{|l|l|r|}
\hline & Al Fitrah & \\
Journal Of Early Childhood Islamic Education & Level Pemahaman Matematika Model \\
ISSN : 2599-2287 E-ISSN : 2622-335X & Pirie dan Kieren Pada Anak Usia Dini \\
& Dodi Isran \\
\hline
\end{tabular}

antara lain adalah primitive knowing $(\mathrm{Pk})$, image making $(\mathrm{lm})$, image having (lh), properly noticing (Pn), formalising $(\mathrm{F})$, Observising (O), structuring (S), dan inventising (Iv).

\section{Level Pemahaman $P$ engetahuan}

\section{Sederhana (Primitive Knowing)}

Pemahaman pada level ini adalah pemahaman yang paling mendasar untuk membangun pemahaman berikutnya. Pemahaman yang terbentuk dari pengetahuan sederhana yang dimiliki oleh siswa. Yang dapat diperoleh dari pengetahuanpengetahuan sebelumnya. Sehingga menjadi landasan untuk Perkembangan pemahaman matematika selajutnya atau dapat diartikan sebagai titik awal dari Perkembangan tersebut. $^{7}$

$$
\text { Perkembangan pemahaman }
$$
matematika selajutnya atau dapat diartikan sebagai titik awal dari perkembangan tersebut.8 Kemudian fakta ini didukung oleh pernyataan Parameswaram $^{8}$ tentang level ini yaitu sebagai berikut :

7 Fatrima Santri Syafri dan Dodi Isran, Pembelajaran Matematika Model Teori Pirie dan Kieren. Jurnal Edudikara Vol.1 No.2 Desember 2016. Hal.45

8 Parameswaran, R. (2010). Expert Mathematicians" Approach to Understanding Definitionsfhe Mathematics Educator. Volume 20, Nomor 1: 43
" $T$ he innermost level of the model is referred to as primitive knowing, for this level describes the process of initial attempts to understand a new concept (such as functions) through actions involving the concept (adding or composing functions, evaluating a function at a point, etc. ) or representations of the concept (such as the graph of a function).

Makna dari pernyataan tersebut adalah menyatakan bahwa tingkat terdalam dari model ini disebut sebagai pengetahuan sederhana, dimana pada tingkat ini menjelaskan suatu proses sebagai upaya awal untuk memahami suatu ' konsep baru (misalnya pada materi fungsi) melalui tindakan pada level ini, melibatkan beberapa konsep fungsi seperti menambahkan atau menulis fungsi, mengevaluasi fungsi pada suatu titik atau representasi dari konsep fungsi (seperti grafik fungsi).

Menurut analisa beberapa pernyataan tersebut, level pemahaman ini adalah level yang paling sederhana atau level titik awal dari pemahaman matematika. Level yang mendasar ini didapat siswa dari pendidikan usia dini dalam pemahaman matematika. Contohnya mengenal apa yang dimaksud 


\begin{tabular}{|l|l||r|}
\hline & Al Fitrah & Level Pemahaman Matematika Model \\
Journal of Early Childhood Islamic Education & Pirie dan Kieren Pada Anak Usia Dini \\
ISSN : 2599-2287 E-ISSN : 2622-335X & Dodi Isran \\
Vol.2 No.1 Juli 2018 & \\
\hline
\end{tabular}

dengan simbol 2 (dua) pada anak usia dini.

Kemampuan awal siswa yang terbentuk adalah siswa usia dini dapat memahami bahwa simbol 2 adalah menyatakan sebanyak dua seperti contoh banyak buku sebanyak dua buah buku.

Pemahaman siswa ini, akan berkembang dengan pemahaman awal tersebut Misalnya siswa dapat menyatakan penjumlahan.

\section{Level Pemahaman Membuat Gambaran (Image Making)}

Level pemahaman ini siswa membuat pemahaman dari pengetahuan sederhana atau pengetahuan awal mereka dan menggunakannya pada cara yang baru. Siswa membuat gambaran pemahaman mereka dari pengetahuan sebelumnya. Siswa berupaya memahami pengetahuan awal meraka pada materi yang dipelajari sehingga menghasilkan ide baru pada materi tersebut. Pengembangan ide tersebut dapat dilakukan siswa dengan memahami konsep tersebut melalui gambar ataupun contoh-contoh penyelesaian lainnya yang muncul dari perkembangan pengetahuan awal mereka.
Pada level ini, menurut Lyndon Martin dan Susan Pirie ${ }^{9}$ mengemukakan tentang level kedua membuat gambar ( image making) sebagai berikut :

"The first level of understanding to be built on this foundation is that which is termed Image Making. This is the le vel at which learners work at tasks, mental or physical, that are intended to foster some initial or extended conceptions for the topic to be explored. In the case of fractions, Image Making activities would perhaps lead to the learner saying, "Ah, fractions are what you get when you out things up".

Berdasarkan pernyataan tersebut mengemukakan bahwa tingkat pertama dari pemahaman akan dibangun di atas dasar level awal disebut membuat gambar. Ini adalah tingkat di mana siswa bekerja pada tugas-tugas, mental atau flsik, yang dimaksudkan untuk mendorong beberapa konsepsi awal atau diperluas untuk topik yang akan dieksplorasi.

${ }^{9}$ Martin, L, dan Pirie, S. (2000). The Role of Collecting in the Growth of MathematicalUnderstanding. Mathematics Education Research Journal 2000, Volume 12, Nomor 2: hal. 130. 


\begin{tabular}{|l||l|r|}
\hline & Al Fitrah & \\
Journal Of Early Childhood Islamic Education & Level Pemahaman Matematika Model \\
ISSN : 2599-2287 E-ISSN : 2622-335X & Pirie dan Kieren Pada Anak Usia Dini \\
& Dodi Isran \\
\hline
\end{tabular}

Pada level ini, untuk kemampuan awalnya siswa usia dini telah mengetahui beberapa simbol tentang angka 1, 2, 3, 4, 5 dan seterusnya selanjutnya pemahaman siswa berkembang bagaimana menggambarkan beberapa jumlah tersebut pada sebuah penjumlahan.

Sehingga pada level pemahaman ini siswa usia dini dapat membuat gambar tentang penjumlahan beberapa buku seperti pada gambar 2 yang diperoleh siswa dari kemampuan awal siswa dalam mengenal angka.

\section{Level Pemahaman Memiliki Gambaran (Image Having)}

Level ini mengemukakan bahwa siswa telah memiliki gambaran dalam penjumlahan seperti pada level selanjutnya sehingga siswa didorong untuk mengenalsombol penjumlahan $(+)$ dan sama dengan $(=)$.

Maka siswa akan mampu mengenal penjumlahan dari permasalahan yang mereka. miliki dengan telah memperhatikan pola penjumlahan dari perkembangan level pemahman angka dan simbol yang telah mereka pahami pada level pemahaman sebelumnya
Level Pemahaman Memperhatikan Sifat (Property Noticing)

Level pemahaman memperhatikan sifat ini, misalnya seperti contoh sebelumnya siswa dapat memperhatikan bahwa terdapat sifat penjumlahan $(+)$ yang menyatakan sebagai adanya penambahan suatu pola angka yang terbentuk. Selanjutnya siswa akan mengenal pola pengurangan dimana level pemahaman siswa dapat kembali pada level kemampuan awal sebelumnya. lni yang menyatakan bahwa level pemahaman siswa dapat kembali pada level pemahaman sebelumnya.

\section{Level Pemahaman Memformalkan (Formalising)}

Level ini siswa usia dini telah mampu mambuat dan mengaplikasikan sifat-sifat yang telah diketahui pada level sebelumnya. Misalkan dalam menulis simbol penjumlahan di antaranya simbol tambah, sama dengan dan simbol angka.

Sehingga siswa dapat memformalkan pemahaman sebelumnya yang telah mereka ketahui. Seperti masalah di atas siswa mampu memformalkan penjumlahan dalam pola operasi penjumlahan $1+2=3$. 


\begin{tabular}{|l|l||r|}
\hline A1 Fitrah & Level Pemahaman Matematika Model \\
Journal Of Early Childhood Islamic Education & Pirie dan Kieren Pada Anak Usia Dini \\
ISSN : 2599-2287 E-ISSN : 2622-335X & Dodi Isran \\
Vol.2 No.1 Juli 2018 & \\
\hline
\end{tabular}

\section{Level Pemahaman Menngamati} (Observing)

Pada level selanjutnya ini siswa dapat melakukan pengamatan bagaimana penggunaan dari konsep yang telah dihubungkan pada materi tersebut sehingga siswa dapat mengaitkan pola dari penyelesaian tentang teori tersebut dan mampu menggunakan dan mengaitkannya pada permasalahan yang dihadapi pada materi tersebut.

Hal ini sejalan dengan yang dikemukakan oleh ParameswaramH tentang level ini yaitu sebagai berikut :

"At the level titled observing, the learner tries to achieve consistency in his or her thought processes by trying to accommodate existing knowledge structures to fit with the newly acquired knowledge."

Berdasarkan pernyataan tersebut mengatakan bahwa, pada level mengamati, dapat I mencontohkan siswa anak usia dini mencoba secara konsisten dalam proses berpikir mengakomodasikan pengetahuan baru yang mereka dapat diamati untuk mengaitkan pada topik yang dibahas sehingga terbentuklah struktur pengetahuan yang ada dengan pengetahuan yang baru mereka Peroleh.
Pemahaman ini yang dijelaskan pada level berikutnya.

\section{Level Pemahaman Penataan}

\section{(Structuring)}

Level ini anak usia dini telah mampu menyusun pemahaman mereka serta mengaitkannya pada permasalahan atau dalam artian lain anak usia dini telah mampu mengaitkan teorema yang satu dengan teorema yang lainnya. Sehingga siswa mampu membuktikannnya berdasarkan argumen atau pendapat mereka secara logis berdasarkan perkembangan pemahaman matematika sebelumnya

Level mi anak usia dini mampu menyusun pekerjaan/tugas yang diberikan berdasarkan pengamatan tentang sifat yang ditanyakan pada permasalahan. Misalnya pada materi pecahan siswa menyusun jawaban tentang pecahan tersebut berdasarkan dari pengetahuan mereka tentang penjumlahan, dan pengurangan sehingga terbentuk suatu susunan jawaban yang dapat menjawab pertanyaan dari tugas yang diberikan.

\section{Level 8 Penemuan (Inventising)}

Level ini adalah level terakhir pada model Pirei dan Klerin terakhir anak usia dini telah dapat menemukan 


\begin{tabular}{|l||l|r|}
\hline & Al Fitrah & \\
Journal Of Early Childhood Islamic Education & Level Pemahaman Matematika Model \\
ISSN : 2599-2287 E-ISSN : 2622-335X & Pirie dan Kieren Pada Anak Usia Dini \\
& Dodi Isran \\
\hline
\end{tabular}

konsep baru yang sebelumnya belum mereka ketahui. Konsep tersebut berdasarkan pada sebuah pemahaman yang terstruktur dan siswa mampu membuat pertanyaan baru dari permasalahan atau materi yang mereka pelajari. Pada level ini juga siswa mampu menciptakan struktur matematika dan Pengetahuan yang mereka miliki sebelumnya. Misalnya dari pengetahuan penjumlahan siswa mampu menggunakan konsep Pengurangan dari pengetahuan bagaimana konsep menambahkan angka atau bilangan.

Pada level ini siswa telah mampu menyelesaikan tugas yang diberikan, sehingga siswa memiliki pemahaman baru tentang yang belum mereka miliki sebelumnya. Siswa memperoleh pengetahuan baru dari materi yang sedang meraka pelajari. Misalnya dari pengetahuan penjum|ahan baik dalam segi menambahkan atau mengurangkan anak usia dini mampu menemukan konsep sendiri dalam pola perkalian dan pembagian.

\section{Penutup}

Pada anak usia dini level pemahaman matematika yang mereka miliki dapat dilihat salah satunya dengan model Pirie dan Kierz'n. Pirie dan Kierin membagi level pemahaman matematika ini menjadi 8 (delapan) tingkatan pemahaman. Dimana pada tingkatan tersebut anak usia dini dapat kembali pada level atau tingkatan pemahaman matematika sebelumnya. Kedelapan level tersebut adalah sebagai berikut :
1) Level 1 Pengetahuan Sederhana (Primitive Knowing)

2) Level 2 Membuat Gambaran (Image Making)

3) Level 3 Memiliki Gambaran (Image Having)
4) Level 4 Memperhatikan Sifat (Property Noticing)
5) Level 5 Memformalkan (Formalising)

6) Level 6 Mengamati (Observing)

7) Level 7 Penataan (Structuring)

8) Level 8 Penemuan (Inventising)

\section{Daftar Pustaka}

Fatrima Santri Syafri dan Dodi 1sran. 20

1 6. Pembelajaran Matematika Model Teori Pirie dan Kieren. Jumal Edudikara Vol.1 No.2.

Hiebert, J.,\& Carpenter, T.P. 1992. Learning and teaching with understanding. In D.A. Grouws (Ed.), Handbook of research on 


\begin{tabular}{|l||l|r|}
\hline A1 Fitrah & Level Pemahaman Matematika Model \\
\hline Journal Of Early Childhood Islamic Education & Pirie dan Kieren Pada Anak Usia Dini \\
ISSN : 2599-2287 E-ISSN : 2622-335X & Dodi Isran \\
\hline
\end{tabular}

mathematics teaching and

learning. NY: MacMillian.

Martin, L, dan Pirie, S. 2000. The Role

of Collecting in the Growth of

"Membangun Karakter Bangsa

Mathematical Understanding.

Mathematics Education Research

Journal 2000, Volume 12, Nomor

2

NCTM. 2000. Principles and Standars

for School Mathematics. Reston, VA: NCTM.

Novikasari, Ifada 2016 Matematika dalam Program Pendidikan Anak Usia Dini (PAUD). Bunayya: Jurnal Pendidikan Anak, Vol 2 (1)

Parameswaran, R. 2010. Expert

Mathematicians" Approach to Understanding Definitions. The Mathematics Educator. Volume 20, Nomor 1

Pirie, S., Kieren, T. 1989. A recursive theory of mathematical understanding. F or the Learning of Mathematics, 9(3), hal. 11.

Susiswo.2014. Folding Back Mahasiswa

Dalam Menyelesaikan Masalah

Limit Berdasarkan Pengetahuan

Konseptual Dan Pengetahuan

Prosedural. Dalam Prosiding

Seminar Nasional TEQIP

(Teachers Quality Improvement Program) dengan tema 